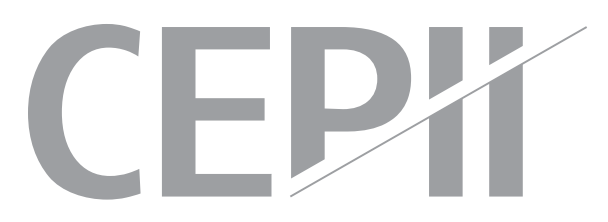

\title{
On the Seemingly Incompleteness of Exchange Rate Pass-through to Import Prices: Do Globalization and/or Regional Trade Matter?
}

Antonia Lopez-Villavicencio \& Valérie Mignon

\section{Highlights}

- We do not find compelling evidence that global factors cause a structural change in the degree of exchange rate pass-through (ERPT).

- Regionalization, defined as a higher proportion of intra-EU imports' share in total imports, reduces the passthrough in a more generalized way.

- ERPT incompleteness generally observed in the literature is in appearance only and not at play when intraEU trade is controlled for.

- ERPT is complete and significant in numerous sectors, meaning that exchange rate changes still exert important pressure on domestic prices. 


\section{Abstract}

This paper assesses the impact of globalization on exchange rate pass-through (ERPT) into import prices in three core eurozone countries. To this end, we consider various indicators of globalization and rely on both aggregated (i.e., country level) and disaggregated (i.e., good level) data. Using quarterly data since 1992, we do not find compelling evidence that global factors cause a structural change in the degree of exchange rate pass-through. Indeed, increased trade openness or lower trade tariffs push up ERPT in some sectors, though results are quite sparse. However, regionalization, defined as a higher proportion of intra-EU imports' share in total imports, reduces the pass-through in a more generalized way. Most importantly, we show that ERPT incompleteness generally observed in the literature is in appearance only and not at play when intra-EU trade is controlled for. Overall, our findings show that ERPT is complete and significant in numerous sectors, meaning that exchange rate changes still exert important pressure on domestic prices.

\section{Keywords}

Exchange Rate Pass-through, Import Prices, Globalization, Eurozone.

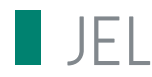

E31, F31, F4, C22.

\section{Working Paper}

\section{CEPI}

CEPII (Centre d'Etudes Prospectives et d'Informations Internationales) is a Frenchinstitute dedicated to producing independent, policyoriented economic research helpful tounderstand the international economic environment and challenges in the areas of trade policy, competitiveness, macroeconomics, international finance and growth.
CEPII Working Paper

Contributing to research in international economics

C C CEPII, PARIS, 2017

All rights reserved. Opinions expressed in this publication are those of the author(s) alone.

$\begin{array}{ll}\text { Editorial Director: } & \text { CEPII } \\ \text { Sébastien Jean } & \text { 113, rue de Grenelle } \\ & 75007 \text { Paris } \\ \text { Production: } & +33153685500 \\ \text { Laure Boivin } & \\ \text { No ISSN: } 1293-2574 & \text { Prw.cepii.fr }\end{array}$




\title{
On the seemingly incompleteness of exchange rate pass-through to import prices: Do globalization and/or regional trade matter? ${ }^{1}$
}

\author{
Antonia López-Villavicencio* and Valérie Mignon ${ }^{\dagger}$
}

\section{Introduction}

The exchange rate pass-through (ERPT from now on), understood as the extent to which an exchange rate change is reflected in import and consumer prices, is a central concept in international trade and macroeconomics, both from theoretical and empirical viewpoints (see Knetter (1989); Campa and Goldberg (2005); and Burstein and Gopinath (2013)). A large body of this literature puts forward that ERPT is incomplete and has been steadily declining over the past few decades.

The partial character of ERPT has received two main explanations: a macroeconomic justification (Monacelli (2005)) in which the incompleteness comes from nominal rigidities leading to unresponsiveness in prices in the short run, and a microeconomic explanation linking the incomplete ERPT to an increasing degree of pricing-to-market behavior of firms (Betts and Devereux (2000)). A common explanation for the decreasing ERPT is that expectations of inflation have become much more solidly anchored in recent years. Indeed, in the context of a stable and predictable monetary policy environment, nominal shocks play a vastly reduced role in driving fluctuations in prices and in the exchange rate (Taylor (2000)). Thus, a stable monetary policy environment - supported by an institutional framework that allows the central bank to pursue a credible and independent policy-contributes to explaining why even sizeable depreciations of the nominal exchange rate have exerted small effects on prices: when the inflation environment is more stable, firms resist passing exchange rate changes on to prices. Similar arguments are developed in Gagnon and Ihrig (2004), Bailliu and Fujii (2004), Devereux, Engel, and Storgaard (2004), Ihrig, Marazzi, and Rothenberg (2006), Marazzi and Sheets (2007), Bouakez and Rebei (2008), Devereux and Yetman (2010) and Dong (2012) where the size of pass-through is a function of the

\footnotetext{
${ }^{1}$ We would like to thank Anne-laure Delatte and Sébastien Jean for helpful remarks and suggestions.

${ }^{*}$ GATE-CNRS and University Lumière Lyon 2, France. Email: lopez@gate.cnrs.fr.

${ }^{\dagger}$ EconomiX-CNRS, University of Paris Nanterre and CEPII, France. Corresponding author: Valérie Mignon, EconomiX-CNRS, University of Paris Nanterre, 200 avenue de la République, 92001 Nanterre Cedex, France. Phone: 331409758 60. E-mail: valerie.mignon@u-paris10.fr
} 
stance of monetary policy.

Recently, López-Villavicencio and Mignon (2016) show that both the level and volatility of inflation, as well as the adoption of an inflation target or the transparency of monetary policy decisions clearly reduce ERPT to consumer prices. However, they find that uncertainty about domestic monetary policy is less relevant for the pass-through to import prices. Other factors than monetary ones may thus be at play in explaining the dynamics of ERPT to import prices.

Based on this evidence, we investigate in this paper if trade integration affects the passthrough to import prices. Indeed, many authors have suggested that the process of globalization brought about important changes in the behavior of some major macroeconomic variables such as inflation, output and interest rates (Milani (2012)). In particular, the globalization hypothesis, in contrast to the traditional explanation centered on monetary policy credibility, is believed to affect the pass-through of foreign marginal costs and the exchange rate into import prices.

More precisely, two theoretical effects are at play. According to the first effect, globalization impacts inflation dynamics through its influence on the degree of competition. Specifically, globalization-which refers here to a rising share of goods sold by foreign firms in the domestic market or factors leading to higher trade integration-impacts imported inflation dynamics through its effect on ERPT into import prices. As a large fraction of consumption and intermediate goods is represented by imported goods, the overall price index becomes more sensitive to external conditions, namely the combined dynamics of nominal exchange rate and foreign marginal costs. The second channel through which globalization influences the dynamics of inflation is, indirectly, via its effect on the pricing strategies of domestic firms selling in the internal market.

While these theoretical effects are clearly established, their outcome is controversial. Specifically, both higher and lower ERPT may result from greater competition. Following Dornbusch (1987) and Benigno and Faia (2016), globalization reflected by greater competition implies higher ERPT. The intensity of exchange rate pass-through depends on the degree of concentration in the market and, in particular, on the share of foreign products in the domestic market. Indeed, greater competition, due to the rise in the share of foreign products sold in a specific industry raises the degree of exchange rate pass-through. Following this mechanism, globalization accentuates the dependence of imported inflation on external 
conditions, and Benigno and Faia (2016) show that there is evidence of an increase in ERPT degree exactly at the time at which the globalization process took place. Their theoretical results are confirmed by an empirical analysis on US sectoral data providing evidence that ERPT has increased in at least half of the sectors considered, especially after 1999, i.e., after the pick up of trade liberalization.

On the opposite, Gust, Leduc, and Vigfusson (2010) argue that increased foreign competition, i.e. greater trade integration, implies lower ERPT. They propose an open economy dynamic general equilibrium model in which strategic complementarity in price setting plays a key role. Indeed, firm's pricing decisions do not only depend on its marginal costs, but also on the prices set by its competitors. This feature implies that it is optimal for a foreign exporter to vary its markup in response to shocks that change the exchange rate, insulating import prices from exchange rate variations. Increased trade integration makes exporters more responsive to the prices of their competitors, leading to a change in pricing behavior that may contribute to the observed decline in the sensitivity of import prices to the exchange rate, lowering the pass-through to prices. Specifically, in their model, Gust, Leduc, and Vigfusson (2010) show that an exporter is encouraged to set a quite high and variable markup when its costs are lower than the other-foreign-firms, and a low and inelastic markup when its costs are high. To complement their theoretical model, Gust, Leduc, and Vigfusson (2010) provide empirical evidence linking the fall in pass-through to lower trade costs. Using industry specific measures of pass-through and trade costs, they show that industries in which the decrease in trade costs has been relatively large have also experienced quite important declines in pass-through.

As shown, the debate related to the theoretical impact of globalization on ERPT is far from being closed. Turning to an empirical viewpoint, the literature that explores the link between globalization and ERPT is very scarce, especially in the non-U.S. case. Our aim in this paper is to fill this gap by running an empirical analysis focusing on countries belonging to the eurozone. As import prices constitute a major transmission channel of changes in the euro on domestic prices and, in turn, inflation and output, analyzing ERPT is of crucial importance in the context of a monetary union. The same exchange rate change may affect eurozone countries differently, depending on their openness to trade degree. Accounting for such different responses of import prices to euro exchange rate changes is important for the conduct of the single monetary policy. It is also worthy of interest with regard to the impact of entering into the union and the success of protocols and processes calling for structural reforms in the EMU (European Monetary Union). Some previous studies have been done in the euro area context among which Schroder and Hufner (2002), Anderton (2003), Hahn (2003), Campa, Goldberg, and Gonzàlez-Mínguez (2005), Campa and 
Gonzàlez-Mínguez (2006), Faruqee (2006), Ben Cheikh and Rault (2016). In this paper, in addition to overcoming the drawback linked to the short time sample used in these studies (with the exception of Ben Cheikh and Rault (2016)), we go further than the existing literature in various ways.

First, instead of considering indifferently all countries of the euro area, we focus on three core economies, depending on their external exposure. ${ }^{2}$ Specifically, we consider Belgium, which presents the highest degree of trade openness among the core countries, France, which is characterized by the lowest one, and Germany, which is at an intermediate level corresponding to EMU aggregate openness degree. Second, to provide a complete and robust picture, we consider various indicators of globalization: (i) an increase in the degree of trade openness, (ii) a higher intra-industry trade, (iii) a higher presence of Chinese imports over total imports, ${ }^{3}$ (iv) lower import tariffs, and (v) higher intra-EU trade as an indicator for regional trade-which can be interpreted as a cost for outside countries but represents a main driver of globalization. Third, as the relevance of globalization in explaining the pass-through dynamics is difficult to assert when using aggregated prices - at it is the case in the bulk of the literature-we also rely on disaggregated data. Using good-level data based on the one-digit Standard International Trade Classification (SITC) enables us to compare ERPT coefficients across goods and should allow us to identify different strategies in the industries. Fourth, an important novelty of the paper is that it specifically accounts for intra-EU trade, i.e. for regional integration. In particular, a large volume of trade being carried inside the euro area, the import prices affecting domestic prices are only those which are not denominated in euro. We thus go further than the previous literature by controlling for such characteristic, allowing us to assess ERPT dynamics for extra-EU trade.

Relying on quarterly data over the 1992Q1-2016Q2 period-2000Q1-2016Q2 for disaggregated data-, our main findings can be summarized as follows. First, while incomplete ERPT is a well known result in the existing literature, this is not the case when intra-EU trade is excluded from the analysis. Indeed, we show that exchange rate changes tend to be mostly reflected in import prices at both aggregated and disaggregated levels, meaning that ERPT is not far from being complete. This finding calls into question previous results in studies on European economies that do not account for the large volume of intra-EU trade, and highlights the necessity of controlling for regional trade to derive reliable con-

\footnotetext{
${ }^{2}$ In addition, it is worth mentioning that a relatively low dispersion of ERPT levels is expected in the euro area, due to the convergence process implied by the monetary union (see, e.g., Ben Cheikh and Rault (2016)). ${ }^{3}$ This indicator based on China is used by Marazzi, Sheets, Vigfusson, Faust, Gagnon, Marquez, Martin, Reeve, and Rogers (2005) who show that Chinese booming exports to the United States play a role in explaining the low ERPT value in the U.S.
} 
clusions. Second, interacting exchange rate changes with globalization indicators shows the absence of clear link between openness and ERPT, except for Germany-a country which has experienced an important rise in its trade exposure leading to greater competition. Third, reasoning at the good level, ERPT is found to be high and complete in various sectors, but its degrees differ across countries. Fourth, while there is sparse evidence that globalization impacts the degree of ERPT at the sectoral level, higher trade openness and lower trade tariffs seem to increase ERPT in some sectors. Lastly, our findings show that, when significant, the effect of a rise in intra-EU trade is negative on ERPT in some sectors, particularly those producing manufactured goods and machinery and transport equipment. This result reflects the wish of domestic firms to maintain their market power and protect against foreign competition in these particular sectors.

This paper is organized as follows. Section 2 briefly describes our methodology. Section 3 presents the data and some stylized facts. Section 4 displays our estimation results, and Section 5 concludes the paper.

\section{Methodology}

The existing literature usually models exchange rate pass-through by considering variations of the following equation:

$$
\Delta m p_{t}=\alpha+\sum_{j=1}^{n} \gamma_{j} \Delta m p_{t-j}+\rho \Delta y_{t}+\lambda \Delta m c_{t}^{*}+\theta \Delta e_{t}+\epsilon_{t}
$$

where $m p$ represents import prices, $y$ is a local demand factor, $m c^{*}$ stands for the exporter marginal cost (i.e., the foreign production costs), $e$ is the nominal effective exchange rate, $i$ denotes the industry and $t$ refers to the period. Our primary concern in this equation is the pass-through elasticity which corresponds to the coefficient on the exchange rate change, namely $\theta$. The case $\theta=1$ refers to a complete ERPT, corresponding to a one-for-one pass-through changes in import prices. Incomplete ERPT occurs when $\theta<1$, i.e., when exporters adjust their markup. Equation (1) is estimated at the aggregated (i.e., country) and product levels using, in the latter case, individual fixed effects. All the variables are expressed in logarithms.

To explore the global factors' dimension of pass-through, our empirical strategy consists in extending the benchmark ERPT equation as follows:

$$
\Delta m p_{t}=\alpha+\beta_{t}+\sum_{j=1}^{n} \gamma_{j} \Delta m p_{t-j}+\rho \Delta y_{t}+\lambda \Delta m p_{t}^{*}+\theta \Delta e_{t}+\theta^{C}\left(\Delta e_{t} \times C_{t}\right)+C_{t}+\epsilon_{t}
$$


where $C$ is an indicator of trade integration: changes in trade openness, changes in intraindustry trade, changes in tariffs for a country's imports, changes in the weight of China in a country i's exports, and changes in intra-EU imports share. In Equation (2), we interpret a significant coefficient $\theta^{C}$ as evidence that ERPT is affected by global factors.

\section{Data}

\subsection{Time sample}

The period covered in the present study depends on both the availability and the level of disaggregation of data. Indeed, exchange rate pass-through estimates in the literature are usually confronted with a trade-off between sectoral disaggregation level of data and period coverage (Gaulier, Lahrèche-Révil, and Méjean (2008)). Basically, estimates based on aggregated price data allow for a larger time span coverage. However, the use of aggregated price series limits the possibility to identify the structural determinants of the pass-through (to detect differences regarding price discrimination or product differentiation for instance). Working on disaggregated price data offers more information at the product or good level, but has a cost in terms of data period availability. In this paper, we rely on both, aggregated and disaggregated data for three core eurozone countries, namely Belgium, Germany and France over the period 1992Q1-2016Q2 in the case of aggregated data, and 2000Q12016Q2 for a lower level of disaggregation.

\subsection{Variables}

Regarding the measure of import prices at the aggregated level, we consider extra-EU ${ }^{4}$ import unit value indexes taken from the Eurostat Comext database, defined as the ratio between the value of imported goods in monetary terms and the respective quantity of the goods for extra-EU countries. Turning to the disaggregated (i.e., good) level, import unit value indexes of seven sectors (panels) from the Standard International Trade Classification (SITC) industrial good-level data were obtained from the same source. Sub-sections (i.e., panel members) correspond to two-digit sectors or aggregations of them (see Table 11 in Appendix). One industry has been excluded from the analysis, namely mineral fuels, lubricants and related materials (SITC 3 ), due to the peculiar nature of the sector. ${ }^{5}$

\footnotetext{
${ }^{4}$ Extra-EU refers to transactions with all the countries outside the EU, namely the rest of the world except the $28 \mathrm{EU}$ member states.

${ }^{5}$ In particular, the industry evolution is more likely to be related to legal changes and natural factors rather than trade.
} 
In Equation (1), both marginal costs and importer's demand characteristics are highly difficult to evaluate since they are not directly observable, so the use of proxies is common in the literature. In our specification, in the spirit of Marazzi, Sheets, Vigfusson, Faust, Gagnon, Marquez, Martin, Reeve, and Rogers (2005) and Marazzi and Sheets (2007), we take the aggregated OECD foreign Producer Price Index (PPI) as the proxy for production costs. For the local demand factor, we use the GDP as it is usually done in the literature (see, e.g., Campa, Goldberg, and Gonzàlez-Mínguez (2005)). The exchange rate corresponds to the nominal effective exchange rate provided by the Bank of International Settlements (BIS), an increase in the index indicating a depreciation.

\subsection{Indicators of globalization}

Let us now describe our five indicators of globalization. First, at the aggregated and disaggregated levels, trade openness is defined as the sum of extra-EU exports and imports over GDP. Overall and disaggregated trade values are collected from the Comext database. Note that, according to our previous discussion (see Section 1), the sign of the ERPT coefficient can be positive or negative. Indeed, following Benigno and Faia (2016), $\theta^{C}$ should be positive and significant if we expect that higher trade openness implies that there are more foreign firms competing in the destination market. In this case, globalization affects the dynamics of imported inflation through its effect on ERPT into import prices, the rise in the share of foreign products in the domestic market increasing the pass-through degree. However, in case of strategic complementarity in setting prices, a foreign exporter does not want its price to deviate too far from its competitors. Thus, the foreign exporter's price becomes more responsive to the prices of its competitors as its markup increases. As a consequence, it is optimal for a firm to vary its markup more and its price less in response to an exchange rate change. Accordingly, we should observe a reduction of the pass-through of exchange-rate changes to import prices with higher trade integration $\left(\theta^{C}\right.$ should be negative and significant).

Second, we also evaluate how China's presence in total imports may have affected the pricing decisions of exporters from other countries. We therefore consider China's imports share over total imports as well as China's share in each SITC sector (see Marazzi, Sheets, Vigfusson, Faust, Gagnon, Marquez, Martin, Reeve, and Rogers (2005)). Our third global indicator is a measure of intra-industry trade. Here, the underlying hypothesis is that increasing levels of intra-industry trade reflect higher product differentiation with respect to foreign competitors. Indeed, as shown by Caves (1998), product differentiation leads to 
increasing levels of intra-industry trade among countries, providing opportunities to develop new market-niches. In order to test for this hypothesis, we employ the Grubel-Lloyd index of intra-industry trade I/T (see Lipsey (1976)), which is computed as follows:

$$
I / T_{t}=2 \times \frac{\min \left(M_{t} ; X_{t}\right)}{\left(M_{t}+X_{t}\right)}
$$

where $M$ denotes extra-EU imports and $X$ stands for extra EU-exports (of each SITC sector in the disaggregated analysis), in the considered country. The index ranges between zero (no intra-industry trade) and one (perfect intra-industry trade), and captures the level of product heterogeneity and trade complementarity between each sector-country pair and the trading partners. We interpret an increase in intra-industry trade as an adjustment to trade liberalization. Indeed, as suggested by Colantone, Coucke, and Sleuwaegen (2015), the IIT index is likely to grow following firms' strategic reactions to global integration, in terms of product differentiation and production off-shoring. ${ }^{6}$

Our fourth measure of globalization is based on trade tariffs at the aggregated and sectoral levels. Although tariffs represent only a fraction of overall trade costs, they remain an important underlying factor towards greater trade integration. With this respect, Gust, Leduc, and Vigfusson (2010) argue that, with lower costs, foreign exporters should reduce their prices and the home country's import share should rise. Due to the decrease of foreign exporters' prices relative to their competitors (i.e., the domestic firms), the formers can increase their markups and still gain market share. On the contrary, the prices for domestic goods augment relative to their competitors, and domestic firms have to cut their markups in reaction to stronger competition from abroad. Higher markups on foreign goods reinforce strategic complementarity and foreign exporters become more willing to vary their markups in response to cost shocks. Thus, according to Gust, Leduc, and Vigfusson (2010), a decline in trade costs should cause a fall in the pass-through (i.e., $\theta^{C}$ should be positive). Alternatively, we could argue that exporters who face high tariff rates will face a higher degree of local competition in the markets to which they export and hence will be more limited in passing exchange rate changes onto the prices that they charge. Reasoning this way, we could expect industries protected with higher tariff rates to have lower ERPT (i.e., $\theta^{C}$ should be negative). At the country level, data on import tariff rates for the European Union are retrieved from the UNCTAD Trade Analysis Information System (TRAINS). Data are annual and correspond to the mean effective applied tariff

\footnotetext{
${ }^{6}$ For instance, Bernard, Jensen, and Schott (2006) present evidence that companies adjust to increasing import pressure by changing their product-mix towards higher value-added goods, characterized by higher export potential and lower intensity of cost-based foreign competition. Moreover, low value-added goods are increasingly imported, in particular from low-wage countries.
} 
rate of the following non-agricultural and non-fuel products: manufactured goods, ores and metals, chemical products, machinery and transport equipment, and other manufactured goods. Next, we match each SITC sector and sub-sector, with data obtained from the Integrated Database of the World Trade Organization (WTO) at the Harmonized System (HS) 6-digit product. In particular, our measure of tariff corresponds to the average of Add Valorem Duties. ${ }^{7}$

To provide a complete picture, we consider a last measure of globalization reflecting intraEU trade, which may be interpreted as a regional-i.e., EU-based-integration measure, representing a cost for the outside countries. We define this measure as the ratio of intraEU imports over total imports. The underlying idea is as follows. Trade barriers having been removed and euro being adopted as a common currency in the euro area, there is a higher proportion of trade in the same currency and, in turn, a smaller share of "output" exposed to exchange-rate fluctuations. These characteristics should affect the way foreign firms pass exchange-rate shocks onto prices as they reduce the market power of exporters outside the eurozone.

\subsection{Descriptive statistics}

Tables 1 and 2 provide some descriptive statistics referring to our five different globalization indicators and their growth over the period under study. At the country level (Table 1), Belgium is the country displaying the highest degree of trade openness. However, the level of trade exposure is increasing everywhere, particularly in Germany in addition to Belgium. France is the less opened economy and is the country which exhibits the lowest trade exposure growth. At the industry level (Table 2), openness is relatively higher for chemicals and related products (SITC 5), machinery and transport equipment (SITC 7) and miscellaneous manufactured articles (SITC 8), and it has specially increased for animal and vegetable oils (SITC 4) in France and Germany and miscellaneous manufactured articles (SITC 8) in all countries.

Looking at the figures in Table 2 another trend seems to emerge: Chinese imports account for about 35 percent in miscellaneous manufactured articles and, while being much lower in other sectors such as chemicals, they have been increasing over time in all panels. This is particularly the case in machinery, even though the average tariff rate increased slightly over the period. Intra-industry trade, in turn, is very heterogeneous among the different

\footnotetext{
${ }^{7}$ We use the applied tariff which corresponds to the tariff that is actually charged on an import. The corresponding matchings are available upon request from the authors.
} 
sectors in the three countries but, as it is known in the literature, it tends to be higher for manufactured goods than for raw materials or primary goods. Finally, it is interesting to note that intra-EU imports represent more than 70 per cent in several sectors. However, regional trade has decreased in sectors such as manufacturing or chemicals (except in Germany).

Table 1 - Descriptive statistics on globalization and regional indicators at the country level

\begin{tabular}{|c|c|c|c|c|c|c|c|c|c|c|}
\hline \multirow[b]{3}{*}{ Country/Panel } & \multicolumn{8}{|c|}{$\begin{array}{ll}\text { Extra-EU trade } \\
\end{array}$} & \multirow{2}{*}{\multicolumn{2}{|c|}{$\begin{array}{c}\text { Total trade } \\
\text { Intra-EU imports }\end{array}$}} \\
\hline & \multicolumn{2}{|c|}{ Trade openness } & \multicolumn{2}{|c|}{ China's share } & \multicolumn{2}{|c|}{ IIT } & \multicolumn{2}{|c|}{ Tariffs } & & \\
\hline & Level & Growth & Level & Growth & Level & Growth & Level & Growth & Level & Growth \\
\hline Belgium & 0.480 & 3.310 & 0.087 & 4.905 & 0.953 & 0.266 & 2.183 & -1.017 & 0.682 & -0.634 \\
\hline France & 0.115 & 2.071 & 0.088 & 7.047 & 0.663 & 1.800 & 2.183 & -1.017 & 0.650 & -0.111 \\
\hline Germany & 0.267 & 2.846 & 0.100 & 5.585 & 0.897 & -0.615 & 2.183 & -1.017 & 0.539 & -0.259 \\
\hline
\end{tabular}

Notes: This table reports the average values of the globalization indicators over the considered period. Statistics are based on extra-UE trade (i.e., after having removed intra-EU trade) except in the case of intra-EU imports' share.

\section{Results}

Let us first consider the estimation of our baseline Equation (1). The corresponding results are presented in Table 3. As shown, the pass-through estimates present the expected positive and significant sign: an increase in the nominal exchange rate translates into a depreciation of the currency and should normally be followed by a rise in prices. Moreover, ERPT is higher than 0.9 in Belgium and France, meaning that it is not far from being complete. In other words, there is almost a one-to-one pass-through changes in import prices. For the sake of completeness, Table 3 also displays the results regarding estimation of Equation (1) (i) when a dummy variable for the introduction of the euro is included, ${ }^{8}$ and (ii) if we restrict the sample size to the 2002Q1-2016Q4 period. As shown, while the dummy variable is non-significant except for Germany, ERPT degree has strongly increased in all countries after the adoption of the common currency, in line with the results of Benigno and Faia (2016). With regard to the statistics displayed in Tables 1 and 2, this rise in ERPT degree may be partly explained by the reduction in intra-EU trade.

These findings highlight the importance, and even the necessity, of controlling for intra-EU trade to correctly assess the degree of ERPT. To further illustrate and for comparative

${ }^{8}$ Specifically, Equation (1) is written as follows:

$$
\Delta m p_{t}=\alpha+\sum_{j=1}^{n} \gamma_{j} \Delta m p_{t-j}+\rho \Delta y_{t}+\lambda \Delta m c_{t}^{*}+\theta \Delta e_{t}+\delta D U M_{t}+\epsilon_{t}
$$

where $D U M T_{t}$ is the dummy variable that takes the value of 1 for $2002 \mathrm{Q} 1$ and all subsequent periods, zero otherwise. 
Table 2 - Descriptive statistics on globalization and regional indicators at the industry level. Period averages

\begin{tabular}{|c|c|c|c|c|c|c|c|c|c|c|}
\hline & \multicolumn{8}{|c|}{ Extra-EU trade } & \multirow{2}{*}{\multicolumn{2}{|c|}{$\begin{array}{l}\text { Total trade } \\
\text { Intra-EU } \\
\text { imports }\end{array}$}} \\
\hline & \multicolumn{2}{|c|}{$\begin{array}{c}\text { Trade } \\
\text { openness }\end{array}$} & \multicolumn{2}{|c|}{$\begin{array}{l}\text { China's } \\
\text { share }\end{array}$} & \multicolumn{2}{|c|}{ IIT } & \multicolumn{2}{|c|}{$\begin{array}{l}\text { Trade } \\
\text { tariffs }\end{array}$} & & \\
\hline & Level & Growth & Level & Growth & Level & Growth & Level & Growth & Level & Growth \\
\hline \multicolumn{11}{|l|}{ Belgium } \\
\hline SITC $0-1$ & 0.004 & 2.244 & 0.028 & 2.400 & 0.519 & 1.331 & 9.780 & -0.900 & 0.791 & -0.189 \\
\hline SITC 2 & 0.002 & -0.683 & 0.045 & 5.133 & 0.491 & 1.749 & 2.483 & -0.166 & 0.585 & -0.324 \\
\hline SITC 4 & 0.000 & -3.104 & n.a & n.a & 0.742 & 1.980 & 5.446 & -0.328 & 0.848 & 1.540 \\
\hline SITC 5 & 0.014 & 3.120 & 0.064 & 6.990 & 0.795 & -0.474 & 4.638 & -0.214 & 0.734 & -1.039 \\
\hline SITC 6 & 0.012 & -0.284 & 0.202 & 8.214 & 0.771 & -0.176 & 2.697 & -1.717 & 0.673 & -1.267 \\
\hline SITC 7 & 0.011 & -0.666 & 0.155 & 9.920 & 0.747 & -0.638 & 2.622 & 0.483 & 0.679 & -0.735 \\
\hline SITC 8 & 0.014 & 2.882 & 0.343 & 3.157 & 0.483 & 1.671 & 3.787 & 0.295 & 0.481 & -1.582 \\
\hline \multicolumn{11}{|l|}{ France } \\
\hline SITC $0-1$ & 0.001 & 1.171 & 0.005 & 0.889 & 0.432 & 0.225 & 9.780 & -0.900 & 0.810 & 0.228 \\
\hline SITC 2 & 0.000 & -1.159 & 0.046 & 4.000 & 0.629 & 0.870 & 2.483 & -0.166 & 0.594 & 0.197 \\
\hline SITC 4 & 0.000 & 3.895 & n.a & n.a & 0.587 & -0.874 & 5.446 & -0.328 & 0.742 & -0.772 \\
\hline SITC 5 & 0.003 & 1.151 & 0.062 & 5.927 & 0.648 & -1.421 & 4.638 & -0.214 & 0.735 & -0.172 \\
\hline SITC 6 & 0.001 & -0.848 & 0.193 & 8.522 & 0.723 & 0.692 & 2.697 & -1.717 & 0.813 & -0.116 \\
\hline SITC 7 & 0.006 & -2.177 & 0.169 & 10.805 & 0.730 & -0.246 & 2.622 & 0.483 & 0.723 & 0.222 \\
\hline SITC 8 & 0.007 & 3.342 & 0.386 & 3.201 & 0.383 & 2.035 & 3.787 & 0.295 & 0.678 & -0.033 \\
\hline \multicolumn{11}{|l|}{ Germany } \\
\hline SITC $0-1$ & 0.001 & 2.719 & 0.055 & 3.797 & 0.563 & 1.119 & 9.780 & -0.900 & 0.763 & 0.273 \\
\hline SITC 2 & 0.000 & -0.064 & 0.106 & 0.351 & 0.646 & 2.013 & 2.483 & -0.166 & 0.663 & 0.921 \\
\hline SITC 4 & 0.000 & 6.708 & n.a & n.a & 0.366 & 0.260 & 5.446 & -0.328 & 0.740 & -0.132 \\
\hline SITC 5 & 0.003 & 3.129 & 0.087 & 5.628 & 0.614 & -0.274 & 4.029 & -0.290 & 0.757 & 0.261 \\
\hline SITC 6 & 0.003 & 0.746 & 0.185 & 7.165 & 0.779 & -0.275 & 2.697 & -1.717 & 0.695 & -0.099 \\
\hline SITC 7 & 0.003 & 3.129 & 0.087 & 5.629 & 0.614 & -0.274 & 2.622 & 0.483 & 0.757 & 0.261 \\
\hline SITC 8 & 0.006 & 2.550 & 0.350 & 3.125 & 0.604 & 0.061 & 3.787 & 0.295 & 0.487 & 0.593 \\
\hline
\end{tabular}

Notes: This table reports the average values of the globalization indicators at the industry level over the considered period. Statistics are based on extra-UE trade (i.e., after having removed intra-EU trade) except in the case of intra-EU imports' share. SITC 0 and 1: Food, beverages and tobacco, SITC 2: Crude materials, inedible, except fuels, SITC 4: Animal and vegetable oils, fats and waxes, SITC 5: Chemicals and related products, SITC 6: Manufactured goods, SITC 7: Machinery and transport equipment, SITC 8: Miscellaneous manufactured articles. 
purposes, Table 12 in Appendix shows the estimation results when intra-EU trade is not controlled for (i.e., when total trade is considered). These results confirm previous findings of the literature regarding the incompleteness of ERPT (see Engel (2002), Campa and Goldberg (2005), Marazzi and Sheets (2007), Bouakez and Rebei (2008) and Gust, Leduc, and Vigfusson (2010)). ERPT is even found to be non significant in France. Clearly, excluding intra-EU trade is thus an imperative to correctly evaluate the exchange-rate passthrough in European countries: not discarding intra-EU trade when assessing the degree of ERPT to import prices strongly biases the results in favor of incomplete pass-through.

Table 3 - ERPT coefficients at the country level. Extra-EU trade

\begin{tabular}{|c|c|c|c|}
\hline & \multicolumn{2}{|c|}{ 1992Q1-2016Q4 } & \multirow{2}{*}{$\begin{array}{c}\text { After } 2002 \mathbf{Q 1} \\
\text { Coeff } \\
(t \text {-stat })\end{array}$} \\
\hline & $\begin{array}{c}\text { Coeff. } \\
\text { (t-stat) }\end{array}$ & $\begin{array}{c}\text { Coeff. } \\
\text { (t-stat) }\end{array}$ & \\
\hline \multicolumn{4}{|l|}{ Belgium } \\
\hline$\theta$ & $\begin{array}{l}0.931 \\
(2.76)\end{array}$ & $\begin{array}{l}0.883 \\
(2.61)\end{array}$ & $\begin{array}{l}1.397 \\
(2.76)\end{array}$ \\
\hline dummy Euro & & $\frac{-1.608}{(-1.03)}$ & \\
\hline \multicolumn{4}{|l|}{ France } \\
\hline$\theta$ & $\begin{array}{l}0.932 \\
(2.81)\end{array}$ & $\begin{array}{c}0.961 \\
(2.90)\end{array}$ & $\begin{array}{l}1.287 \\
(2.90)\end{array}$ \\
\hline dummy Euro & & $\begin{array}{c}1.054 \\
(1.13)\end{array}$ & \\
\hline \multicolumn{4}{|l|}{ Germany } \\
\hline$\theta$ & $\begin{array}{c}0.698 \\
(3.85)\end{array}$ & $\begin{array}{l}0.763 \\
(3.97)\end{array}$ & $\begin{array}{l}1.192 \\
(5.16)\end{array}$ \\
\hline dummy Euro & & $\begin{array}{l}2.01 \\
(1.14)\end{array}$ & \\
\hline
\end{tabular}

Notes: This table reports the estimated ERPT coefficients from Equation (1). Corresponding $t$-statistics are given between parentheses. Estimation based on extra-UE trade (i.e., after having removed intra-EU trade). Dummy euro is a dummy variable that takes the value of 1 for $2002 \mathrm{Q} 1$ and all subsequent periods, zero otherwise.

\subsection{Accounting for globalization}

To assess the role of globalization at the country level, Table 4 reports the estimation results of Equation (2). We consider the five afore mentioned indicators in favor of globalization, namely: (i) an increase in the degree of trade openness, (ii) a higher intra-industry trade, (iii) a higher presence of Chinese imports over total imports, (iv) lower import tariffs, and (v) higher intra-EU trade as a regional globalization measure. 
As shown, the interactive effect between exchange rate changes and globalization is mostly non significant. This means that an increase in product differentiation with respect to foreign competitors, in the share of products from China in total imports and in the share of intra-UE imports, as well as a decline in import tariffs do not contribute to explain the ERPT to import prices, at least at the aggregate level. The sole significant interactive terms are obtained when considering growth in trade openness and intra-industry trade for Germany and a higher presence of Chinese imports over total imports in France, suggesting that globalization tends to slightly increase the ERPT degree. Regarding Germany, these findings can be related to the fact that German economy has known an important rise in trade openness over the period under study, leading to greater competition. In line with the argument developed by Benigno and Faia (2016), this growing competition due to the increase in the share of foreign products pushes up the degree of ERPT. In other words, there is slight evidence that the impact of firms' entry on pass-through outweighs the effect of markup adjustments at the intensive margin.

While overall evidence regarding the pass-through effect of global factors is quite weak, it is worth noticing that their impact can operate through other channels. For instance, as recalled by Marazzi and Sheets (2007), pricing decisions of exporters from other countries may have been affected by the efforts made to remain competitive against China. Chinese economy has also proven its high capacity to win market share, making credible the threat of its potential competition and constraining other exporters from passing through exchange rate shocks. In addition and at a more general level, if there is heterogeneity prevailing at the industry level, results based on aggregated import prices present aggregation bias, suggesting the importance of assessing ERPT degree at the sectoral level with disaggregated data. 


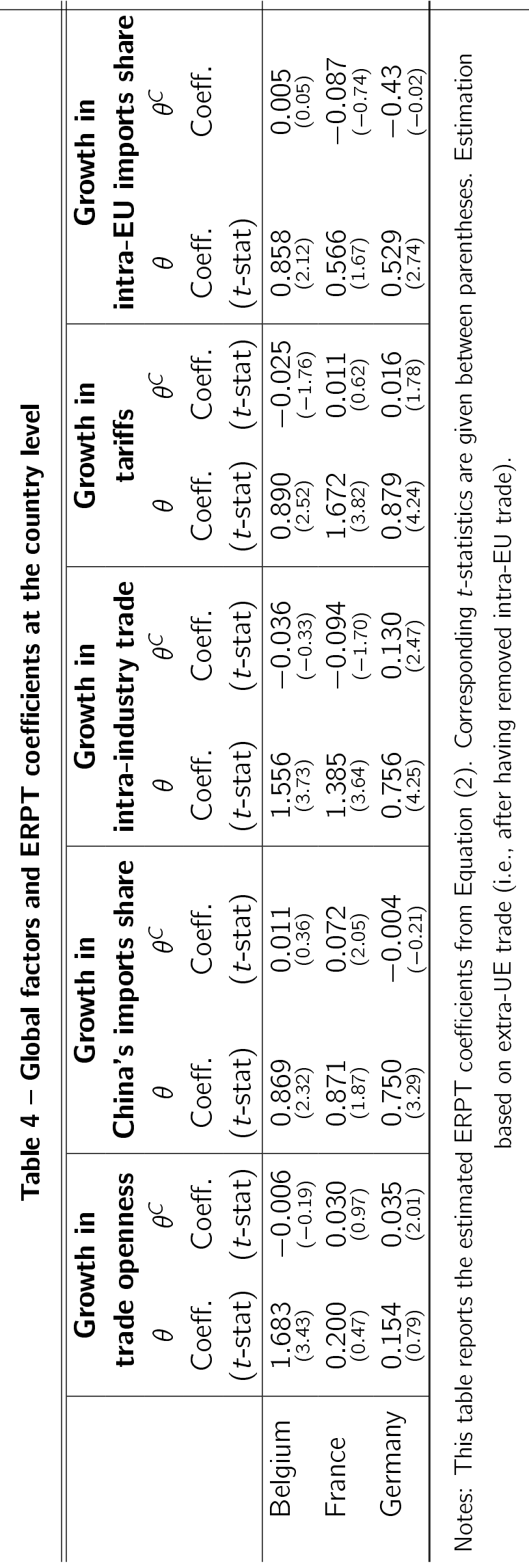




\subsection{Using disaggregated data: accounting for the good level}

To complement our previous country-level results, let us now estimate ERPT into import prices at a disaggregated level, using the two-digit level of disaggregation in the SITC classification. Analyzing ERPT at the good level allows us to account for the fact that the shift in the composition of imports towards goods whose prices are less sensitive to exchange rate changes has contributed to the "seemingly" pass-through decline. The corresponding results are reported in Table $5 .^{9}$

As shown, ERPT is found to be quite high or even complete in most sectors. These findings again illustrate the importance of controlling for intra-EU trade in assessing the effect of exchange rate changes to import prices. ${ }^{10}$ However, the estimates strongly vary depending on the type of goods. The highest ERPT coefficients are generally obtained for goods belonging to SITC 8, SITC 7 and SITC 2 which are the sectors the most commodityintensive. On the whole, the exchange rate effect on the prices of imported goods comes principally through its indirect effect on commodity prices: in commodity-intensive sectors, foreign producers have strong market power and face very weak domestic competition, and, consequently, the world price passed on when the exchange rate fluctuates. The declining share of commodity-intensive goods for which ERPT is higher than for other goods, may thus explain the declining pass-through reported in several studies (see, e.g. LópezVillavicencio and Mignon (2016) and the references therein). For some industries, such as those concerned with manufactured goods (SITC 6), the pass-through strongly differs between countries - the value of ERPT degree for Belgium being about two times that of France. ${ }^{11}$ This can be explained by the fact that these industries are more oriented towards product differentiation, leading to distinct ERPT degrees in different countries.

\subsection{Accounting for globalization at the good level}

Tables 6 to 10 display the estimation results at the disaggregated level of Equation (2). As shown, there is no clear-cut evidence regarding how global factors affect the way for-

\footnotetext{
${ }^{9}$ Note that at the disaggregated level we use panel data techniques. The equations are then estimated by the GMM one-step estimator for each SITC sector and the panel members are the divisions in each Section. ${ }^{10}$ Indeed, working with overall unit value indices at a disaggregated level for the euro area countries, Campa, Goldberg, and Gonzàlez-Mínguez (2005) find a ERPT rarely higher than 60-70 per cent.

${ }^{11}$ It is worth mentioning that the share of manufactured goods ranks at the first place in the import structure of Belgium (in 2015, source: Eurostat), highlighting the fact that a link may exist between ERPT degree and the structure of imports of the considered countries. This hypothesis is also supported by the fact that for Germany and France, high ERPT degrees are observed for industries belonging to SITC 8 and 7, which also play a key role in the import structure of these two countries.
} 
Table 5 - ERPT coefficients at the good level (SITC classification)

\begin{tabular}{|c|c|c|c|c|c|c|c|}
\hline Country & $\begin{array}{c}\text { SITC 0\&1 } \\
\text { Coeff. } \\
\text { (t-stat) }\end{array}$ & $\begin{array}{l}\text { SITC } 2 \\
\text { Coeff. } \\
\text { (t-stat) }\end{array}$ & $\begin{array}{c}\text { SITC } 4 \\
\text { Coeff. } \\
\text { (t-stat) }\end{array}$ & $\begin{array}{c}\text { SITC } 5 \\
\text { Coeff. } \\
\text { (t-stat) }\end{array}$ & $\begin{array}{c}\text { SITC } 6 \\
\text { Coeff. } \\
\text { (t-stat) }\end{array}$ & $\begin{array}{c}\text { SITC } 7 \\
\text { Coeff. } \\
\text { (t-stat) }\end{array}$ & $\begin{array}{c}\text { SITC } 8 \\
\text { Coeff. } \\
\text { (t-stat) }\end{array}$ \\
\hline Belgium & $\begin{array}{c}0.989 \\
(6.49)\end{array}$ & $\begin{array}{c}1.575 \\
(5.92)\end{array}$ & $\begin{array}{l}0.934 \\
(3.12)\end{array}$ & $\begin{array}{c}1.342 \\
(5.03)\end{array}$ & $\begin{array}{l}1.326 \\
(5.52)\end{array}$ & $\begin{array}{c}1.366 \\
(9.25)\end{array}$ & $\begin{array}{c}2.098 \\
(7.35)\end{array}$ \\
\hline J-stat & 0.146 & 0.478 & 0.815 & 0.278 & 0.994 & 0.899 & 0.162 \\
\hline $\operatorname{AR}(2)$ & 0.312 & 0.773 & 0.913 & 0.663 & 0.349 & 0.343 & 0.062 \\
\hline No.obs. & 684 & 513 & 171 & 456 & 513 & 497 & 456 \\
\hline France & $\frac{0.711}{(10.5)}$ & $\frac{0.712}{(8.20)}$ & $\frac{1.021}{(3.69)}$ & $\frac{0.654}{(4.79)}$ & $\frac{0.632}{(12.8)}$ & $\begin{array}{l}0.873 \\
(7.49)\end{array}$ & $\begin{array}{l}1.413 \\
(16.40)\end{array}$ \\
\hline J-test & 0.429 & 0.899 & 0.215 & 0.258 & 0.995 & 0.789 & 0.300 \\
\hline $\operatorname{AR}(2)$ & 0.574 & 0.915 & 0.417 & 0.246 & 0.184 & 0.238 & 0.074 \\
\hline No. obs. & 684 & 513 & 171 & 456 & 513 & 513 & 399 \\
\hline Germany & $\begin{array}{c}0.702 \\
(5.85)\end{array}$ & $\begin{array}{c}0.783 \\
(5.55)\end{array}$ & $\begin{array}{c}0.655 \\
(3.19)\end{array}$ & $\begin{array}{l}0.677 \\
(4.16)\end{array}$ & $\begin{array}{c}0.491 \\
(6.01)\end{array}$ & $\begin{array}{l}0.904 \\
(6.78)\end{array}$ & $\begin{array}{l}1.233 \\
(8.85)\end{array}$ \\
\hline J-test & 0.791 & 0.357 & 0.998 & 0.296 & 0.900 & 0.700 & 0.739 \\
\hline$A R(2)$ & 0.706 & 0.383 & 0.093 & 0.926 & 0.230 & 0.046 & 0.944 \\
\hline No. obs. & 684 & 513 & 171 & 456 & 513 & 513 & 456 \\
\hline
\end{tabular}

Notes: (a) This table reports the estimated ERPT coefficients from Equation (1), (b) Corresponding $t$-statistics are given between parentheses, (c) Estimation based on extra-UE trade (i.e., after having removed intra-EU trade), (d) SITC 0 and 1: Food, beverages and tobacco, SITC 2: Crude materials, inedible, except fuels, SITC 4: Animal and vegetable oils, fats and waxes, SITC 5: Chemicals and related products, SITC 6: Manufactured goods, SITC 7: Machinery and transport equipment, SITC 8: Miscellaneous manufactured articles, (e) The null hypothesis of the J-test is the validity of instruments, (f) The null hypothesis of the AR(2) test is the absence of serial autocorrelation of order 2.

eign exporters pass-through increasing costs to their prices. Indeed, when significant, the interactive term mostly indicates that higher trade openness or lower tariffs increase the ERPT in some cases. However, higher intra-industry trade and, above all, more regional trade reduce the ERPT. Chinese import share, in turn, seem to play no major role on the pricing decisions of foreign exporters.

More in detail, regarding trade openness, the interactive term is positive and significant for goods belonging to SITC 2 (crude materials, inedible, except fuels) for all the countries, SITC 4 (animal and vegetable oils) except in France, and SITC 7 (machinery and transport equipment) for France. In those cases, greater competition is thus associated with higher ERPT, in line with the arguments developed by Dornbusch (1987) and Benigno and Faia (2016). 
Turning to intra-industry trade, when significant the associated coefficient is mostly negative. This means that for the concerned sectors, higher intra-industry trade tends to lower ERPT. This result is consistent with the fact that for sectors characterized by high levels of intra-industry trade, firms react in terms of product differentiation, leading to lower ERPT. A typical example is given by the German case for which machinery and transport equipment sector plays a central role worldwide in the sense that the negative sign reflects the aim of Germany ro preserve its market shares.

Our findings also illustrate that Chinese firms' market penetration has not caused a structural change in ERPT, the interactive coefficient being rarely significant, except in some special cases such as manufactured goods and miscellaneous manufactures in France and Germany which correspond to sectors in which China is highly competitive. ${ }^{12}$ This means that an increase in the share of China tends to weaken ERPT, reflecting a threat from competition with China in these sectors. Those findings may reflect the wish of domestic firms to preserve their market power and protect against foreign competition in these particular sectors.

However, as an illustration that globalization can act in different ways and has many sides, note the effect of trade tariffs in manufacturing goods (SITC 6): reducing import tariffs clearly increases the ERPT in all the three countries. Contrary to the complementarity hypothesis, what seems to be happening is that exporters who face low tariff rates may also face a low degree of local competition in the markets to which they export and hence will be less limited in passing exchange rate changes onto the prices that they charge. Note that this is also the case in crude materials, inedible, except fuels (SITC 2).

Finally, even though the effects of globalization in the ERPT are not clear-cut, regional trade decreases ERPT to import prices in a more generalized way. Indeed, when significant, the coefficient of the interaction term is always negative, meaning that a higher presence of intra-EU imports in all sectors but SITC 5 tends to lowering ERPT.

\footnotetext{
${ }^{12}$ It is worth mentioning that the manufactured goods sector plays a key role in the Chinese economy since (i) it contributes, with the construction sector, nearly half of China's GDP, and (ii) it is highly competitive and export-oriented.
} 
Table 6 - ERPT and growth in trade openness at the good level

\begin{tabular}{|c|c|c|c|c|c|c|}
\hline \multirow[b]{2}{*}{ SITC } & \multicolumn{2}{|c|}{ Belgium } & \multicolumn{2}{|c|}{ France } & \multicolumn{2}{|c|}{ Germany } \\
\hline & $\begin{array}{c}\theta \\
\text { Coeff. } \\
\text { (t-stat) }\end{array}$ & $\begin{array}{c}\theta^{C} \\
\text { Coeff. } \\
\text { (t-stat) }\end{array}$ & $\begin{array}{c}\theta \\
\text { Coeff. } \\
\text { (t-stat) }\end{array}$ & $\begin{array}{c}\theta^{C} \\
\text { Coeff. } \\
\text { (t-stat) }\end{array}$ & $\begin{array}{c}\theta \\
\text { Coeff. } \\
\text { (t-stat) }\end{array}$ & $\begin{array}{c}\theta^{C} \\
\text { Coeff. } \\
\text { (t-stat) }\end{array}$ \\
\hline SITC $0 \& 1$ & $\begin{array}{c}0.931 \\
(6.52)\end{array}$ & $\begin{array}{c}0.008 \\
(1.62)\end{array}$ & $\begin{array}{c}0.674 \\
(8.20)\end{array}$ & $\begin{array}{c}-0.009 \\
(-2.51)\end{array}$ & $\begin{array}{c}0.625 \\
(5.93)\end{array}$ & $\begin{array}{c}0.006 \\
(1.24)\end{array}$ \\
\hline J-stat & 0.134 & & 0.394 & & 0.062 & \\
\hline $\mathrm{AR}(2)$ & 0.643 & & 0.333 & & 0.803 & \\
\hline SITC 2 & $\begin{array}{l}1.471 \\
(5.85)\end{array}$ & $\begin{array}{l}0.008 \\
(2.10)\end{array}$ & $\begin{array}{l}0.561 \\
(7.08)\end{array}$ & $\frac{0.012}{(4.56)}$ & $\begin{array}{l}0.669 \\
(5.24)\end{array}$ & $\begin{array}{c}0.010 \\
(2.70)\end{array}$ \\
\hline J-stat & 0.589 & & 0.998 & & 0.302 & \\
\hline $\mathrm{AR}(2)$ & 0.476 & & 0.549 & & 0.451 & \\
\hline SITC 4 & $\begin{array}{l}1.603 \\
(4.13)\end{array}$ & $\begin{array}{c}0.029 \\
(4.73)\end{array}$ & $\begin{array}{c}0.542 \\
(9.69)\end{array}$ & $\begin{array}{c}-0.005 \\
(-0.96)\end{array}$ & $\frac{0.994}{(4.52)}$ & $\frac{0.020}{(4.71)}$ \\
\hline J-stat & 1.00 & & 0.998 & & 0.988 & \\
\hline$A R(2)$ & 0.461 & & 0.243 & & 0.255 & \\
\hline SITC 5 & $\begin{array}{l}1.261 \\
(3.94)\end{array}$ & $\begin{array}{c}-0.005 \\
(-0.48)\end{array}$ & $\begin{array}{c}0.596 \\
(4.53)\end{array}$ & $\begin{array}{c}0.008 \\
(1.20)\end{array}$ & $\begin{array}{l}0.785 \\
(9.26)\end{array}$ & $\begin{array}{c}-0.023 \\
(-2.05)\end{array}$ \\
\hline J-stat & 0.325 & & 0.270 & & 0.379 & \\
\hline $\operatorname{AR}(2)$ & 0.647 & & 0.287 & & 0.476 & \\
\hline SITC 6 & $\begin{array}{l}1.252 \\
(6.39)\end{array}$ & $\begin{array}{c}-0.009 \\
(-1.30)\end{array}$ & $\begin{array}{l}0.516 \\
(5.10)\end{array}$ & $\begin{array}{l}0.001 \\
(0.19)\end{array}$ & $\begin{array}{l}0.446 \\
(4.51)\end{array}$ & $\begin{array}{l}0.002 \\
(0.45)\end{array}$ \\
\hline J-stat & 0.995 & & 0.378 & & 0.818 & \\
\hline $\operatorname{AR}(2)$ & 0.424 & & 0.212 & & 0.096 & \\
\hline SITC 7 & $\begin{array}{l}1.355 \\
(8.95)\end{array}$ & $\begin{array}{l}0.005 \\
(0.86)\end{array}$ & $\begin{array}{c}0.797 \\
(8.16)\end{array}$ & $\begin{array}{l}0.015 \\
(1.99)\end{array}$ & $\begin{array}{c}0.764 \\
(6.19)\end{array}$ & $\begin{array}{l}0.005 \\
(0.99)\end{array}$ \\
\hline J-stat & 0.685 & & 0.723 & & 0.608 & \\
\hline $\operatorname{AR}(2)$ & 0.316 & & 0.240 & & 0.061 & \\
\hline SITC 8 & $\begin{array}{l}1.853 \\
(5.53)\end{array}$ & $\begin{array}{c}-0.018 \\
(-1.74)\end{array}$ & $\begin{array}{l}1.262 \\
(11.60)\end{array}$ & $\begin{array}{c}-0.012 \\
(-1.88)\end{array}$ & $\begin{array}{l}1.265 \\
(7.28)\end{array}$ & $\begin{array}{c}-0.005 \\
(-0.54)\end{array}$ \\
\hline J-stat & 0.635 & & 0.998 & & 0.972 & \\
\hline $\operatorname{AR}(2)$ & 0.190 & & 0.087 & & 0.350 & \\
\hline
\end{tabular}

Notes: This table reports the estimated ERPT coefficients from Equation (2). Corresponding $t$-statistics are given between parentheses. Estimation based on extra-UE trade (i.e., after having removed intra-EU trade). 
Table 7 - ERPT and growth in intra-industry trade at the good level

\begin{tabular}{|c|c|c|c|c|c|c|}
\hline \multirow[b]{2}{*}{ SITC } & \multicolumn{2}{|c|}{ Belgium } & \multicolumn{2}{|c|}{ France } & \multicolumn{2}{|c|}{ Germany } \\
\hline & $\begin{array}{c}\theta \\
\text { Coeff. } \\
\text { (t-stat) }\end{array}$ & $\begin{array}{c}\theta^{C} \\
\text { Coeff. } \\
\text { (t-stat) }\end{array}$ & $\begin{array}{c}\theta \\
\text { Coeff. } \\
(t \text {-stat })\end{array}$ & $\begin{array}{c}\theta^{C} \\
\text { Coeff. } \\
\text { (t-stat) }\end{array}$ & $\begin{array}{c}\theta \\
\text { Coeff. } \\
(\text { t-stat })\end{array}$ & $\begin{array}{c}\theta^{C} \\
\text { Coeff. } \\
\text { (t-stat) }\end{array}$ \\
\hline SITC $0 \& 1$ & $\begin{array}{c}0.983 \\
(6.34)\end{array}$ & $\begin{array}{c}-0.009 \\
(-2.29)\end{array}$ & $\begin{array}{l}0.713 \\
(10.01)\end{array}$ & $\begin{array}{c}0.002 \\
(0.58)\end{array}$ & $\begin{array}{c}0.703 \\
(6.06)\end{array}$ & $\begin{array}{c}-0.002 \\
(-0.56)\end{array}$ \\
\hline J-stat & 0.154 & & 0.420 & & 0.065 & \\
\hline $\mathrm{AR}(2)$ & 0.287 & & 0.584 & & 0.726 & \\
\hline SITC 2 & $\begin{array}{c}1.700 \\
(6.77)\end{array}$ & $\begin{array}{l}0.001 \\
(0.31)\end{array}$ & $\begin{array}{l}0.727 \\
(8.47)\end{array}$ & $\begin{array}{c}-0.007 \\
(-2.56)\end{array}$ & $\begin{array}{l}0.798 \\
((5.18)\end{array}$ & $\begin{array}{l}-0.006 \\
(-0.89)\end{array}$ \\
\hline J-stat & 0.516 & & 0.899 & & 0.338 & \\
\hline $\operatorname{AR}(2)$ & 0.984 & & 0.964 & & 0.353 & \\
\hline SITC 4 & $\begin{array}{c}1.248 \\
(4.17)\end{array}$ & $\begin{array}{c}-0.012 \\
(-2.56)\end{array}$ & $\begin{array}{l}0.651 \\
(8.24)\end{array}$ & $\frac{0.016}{(9.63)}$ & $\begin{array}{l}0.835 \\
(3.57)\end{array}$ & $\begin{array}{c}0.004 \\
(0.83)\end{array}$ \\
\hline J-stat & 0.999 & & 0.989 & & 0.999 & \\
\hline $\operatorname{AR}(2)$ & 0.398 & & 0.411 & & 0.302 & \\
\hline SITC 5 & $\begin{array}{c}1.432 \\
(6.67)\end{array}$ & $\begin{array}{c}-0.029 \\
(-4.68)\end{array}$ & $\begin{array}{l}0.675 \\
(5.96)\end{array}$ & $\begin{array}{l}0.007 \\
(1.26)\end{array}$ & $\frac{0.662}{(4.61)}$ & $\frac{0.004}{(1.76)}$ \\
\hline J-stat & 0.375 & & 0.433 & & 0.357 & \\
\hline $\mathrm{AR}(2)$ & 0.840 & & 0.642 & & 0.857 & \\
\hline SITC 6 & $\begin{array}{l}1.331 \\
(5.72)\end{array}$ & $\begin{array}{c}0.009 \\
(1.33)\end{array}$ & $\begin{array}{l}0.623 \\
(8.42)\end{array}$ & $\begin{array}{c}-0.004 \\
(-1.34)\end{array}$ & $\begin{array}{l}0.516 \\
(8.42)\end{array}$ & $\begin{array}{c}0.001 \\
(0.09)\end{array}$ \\
\hline J-stat & 0.992 & & 0.354 & & 0.835 & \\
\hline $\operatorname{AR}(2)$ & 0.299 & & 0.229 & & 0.145 & \\
\hline SITC 7 & $\begin{array}{l}1.379 \\
(9.18)\end{array}$ & $\frac{0.007}{(1.69)}$ & $\begin{array}{l}0.769 \\
(6.45)\end{array}$ & $\begin{array}{l}0.006 \\
(0.84)\end{array}$ & $\frac{0.893}{(6.88)}$ & $\begin{array}{c}-0.027 \\
(-3.64)\end{array}$ \\
\hline J-stat & 0.999 & & 0.495 & & 0.752 & \\
\hline $\mathrm{AR}(2)$ & 0.353 & & 0.245 & & 0.075 & \\
\hline SITC 8 & $\begin{array}{l}1.900 \\
(5.72)\end{array}$ & $\begin{array}{c}-0.006 \\
(-2.65)\end{array}$ & $\begin{array}{l}1.289 \\
(12.50)\end{array}$ & $\begin{array}{c}-0.003 \\
(-0.96)\end{array}$ & $\begin{array}{l}1.291 \\
(7.26)\end{array}$ & $\begin{array}{c}-0.007 \\
(-0.83)\end{array}$ \\
\hline J-stat & 0.537 & & 0.994 & & 0.968 & \\
\hline $\operatorname{AR}(2)$ & 0.190 & & 0.069 & & 0.414 & \\
\hline
\end{tabular}

Notes: This table reports the estimated ERPT coefficients from Equation (2). Corresponding $t$-statistics are given between parentheses. Estimation based on extra-UE trade (i.e., after having removed intra-EU trade). 
Table 8 - ERPT and growth in China's imports at the good level

\begin{tabular}{|c|c|c|c|c|c|c|}
\hline \multirow[b]{3}{*}{ SITC } & \multicolumn{2}{|c|}{ Belgium } & \multicolumn{2}{|c|}{ France } & \multicolumn{2}{|c|}{ Germany } \\
\hline & $\theta$ & $\theta^{C}$ & $\theta$ & $\theta^{C}$ & $\theta$ & $\theta^{C}$ \\
\hline & $\begin{array}{c}\text { Coeff. } \\
\text { (t-stat) }\end{array}$ & $\begin{array}{c}\text { Coeff. } \\
\text { (t-stat) }\end{array}$ & $\begin{array}{c}\text { Coeff. } \\
\text { (t-stat) }\end{array}$ & $\begin{array}{c}\text { Coeff. } \\
\text { (t-stat) }\end{array}$ & $\begin{array}{c}\text { Coeff. } \\
\text { (t-stat) }\end{array}$ & $\begin{array}{l}\text { Coeff. } \\
\text { (t-stat) }\end{array}$ \\
\hline SITC $0 \& 1$ & $\begin{array}{c}1.125 \\
(10.3)\end{array}$ & $\begin{array}{c}-0.003 \\
(-2.56)\end{array}$ & $\begin{array}{c}0.718 \\
(12.5)\end{array}$ & $\begin{array}{c}0.006 \\
(1.80)\end{array}$ & $\begin{array}{c}0.719 \\
(8.01)\end{array}$ & $\begin{array}{c}0.003 \\
(1.49)\end{array}$ \\
\hline J-stat & 0.780 & & 0.290 & & 0.744 & \\
\hline $\operatorname{AR}(2)$ & 0.826 & & 0.242 & & 0.134 & \\
\hline SITC 2 & $\begin{array}{l}1.875 \\
(11.2)\end{array}$ & $\begin{array}{c}-0.001 \\
(-0.24)\end{array}$ & $\begin{array}{l}0.679 \\
(6.27)\end{array}$ & $\begin{array}{c}-0.001 \\
(-0.65)\end{array}$ & $\begin{array}{l}0.574 \\
(6.55)\end{array}$ & $\begin{array}{c}-0.004 \\
(-1.39)\end{array}$ \\
\hline J-stat & 0.998 & & 0.091 & & 0.537 & \\
\hline $\operatorname{AR}(2)$ & 0.432 & & 0.516 & & 0.245 & \\
\hline SITC 5 & $\begin{array}{l}1.579 \\
(6.03)\end{array}$ & $\begin{array}{c}0.002 \\
(0.91)\end{array}$ & $\begin{array}{l}0.839 \\
(5.73)\end{array}$ & $\begin{array}{c}-0.002 \\
(-1.36)\end{array}$ & $\begin{array}{c}0.846 \\
(9.95)\end{array}$ & $\begin{array}{l}0.000 \\
(-0.25)\end{array}$ \\
\hline J-stat & 0.912 & & 0.250 & & 0.985 & \\
\hline $\operatorname{AR}(2)$ & 0.757 & & 0.390 & & 0.183 & \\
\hline SITC 6 & $\begin{array}{l}1.411 \\
(7.45)\end{array}$ & $\underset{(-0.17)}{-0.002}$ & $\begin{array}{c}0.663 \\
(10.2)\end{array}$ & $\begin{array}{c}-0.007 \\
(-2.90)\end{array}$ & $\begin{array}{l}0.525 \\
(6.52)\end{array}$ & $\begin{array}{c}-0.005 \\
(-1.42)\end{array}$ \\
\hline J-stat & 0.988 & & 0.540 & & 0.906 & \\
\hline $\operatorname{AR}(2)$ & 0.059 & & 0.199 & & 0.065 & \\
\hline SITC 7 & $\begin{array}{l}1.202 \\
(8.50)\end{array}$ & $\begin{array}{l}0.007 \\
(3.87)\end{array}$ & $\begin{array}{l}0.894 \\
(8.31)\end{array}$ & $\begin{array}{c}-0.002 \\
(-1.49)\end{array}$ & $\begin{array}{l}0.928 \\
(6.63)\end{array}$ & $\begin{array}{c}-0.003 \\
(-1.51)\end{array}$ \\
\hline J-stat & 0.151 & & 0.812 & & 0.989 & \\
\hline $\mathrm{AR}(2)$ & 0.100 & & 0.224 & & 0.140 & \\
\hline SITC 8 & $\begin{array}{l}1.919 \\
(5.95)\end{array}$ & $\underset{(-0.54)}{-0.007}$ & $\begin{array}{l}1.327 \\
(12.70)\end{array}$ & $\begin{array}{c}-0.011 \\
(-1.85)\end{array}$ & $\begin{array}{c}1.367 \\
(7.74)\end{array}$ & $\begin{array}{c}-0.010 \\
(-2.36)\end{array}$ \\
\hline J-stat & 0.325 & & 0.995 & & 0.974 & \\
\hline $\operatorname{AR}(2)$ & 0.042 & & 0.041 & & 0.713 & \\
\hline
\end{tabular}

Notes: This table reports the estimated ERPT coefficients from Equation (2). Corresponding $t$-statistics are given between parentheses. Estimation based on extra-UE trade (i.e., after having removed intra-EU trade). 
Table 9 - ERPT and growth in import tariffs at the good level

\begin{tabular}{|c|c|c|c|c|c|c|}
\hline \multirow[b]{3}{*}{ SITC } & \multicolumn{2}{|c|}{ Belgium } & \multicolumn{2}{|c|}{ France } & \multicolumn{2}{|c|}{ Germany } \\
\hline & $\theta$ & $\theta^{C}$ & $\theta$ & $\theta^{C}$ & $\theta$ & $\theta^{C}$ \\
\hline & $\begin{array}{l}\text { Coeff. } \\
\text { (t-stat) }\end{array}$ & $\begin{array}{l}\text { Coeff. } \\
\text { (t-stat) }\end{array}$ & $\begin{array}{c}\text { Coeff. } \\
\text { (t-stat) }\end{array}$ & $\begin{array}{c}\text { Coeff. } \\
\text { (t-stat) }\end{array}$ & $\begin{array}{c}\text { Coeff. } \\
\text { (t-stat) }\end{array}$ & $\begin{array}{c}\text { Coeff. } \\
\text { (t-stat) }\end{array}$ \\
\hline SITC $0 \& 1$ & $\begin{array}{c}0.993 \\
(5.62)\end{array}$ & $\begin{array}{c}-0.047 \\
(-2.12)\end{array}$ & $\begin{array}{c}0.737 \\
(9.29)\end{array}$ & $\begin{array}{c}-0.001 \\
(-0.07)\end{array}$ & $\begin{array}{c}0.664 \\
(5.11)\end{array}$ & $\begin{array}{c}-0.041 \\
(-1.55)\end{array}$ \\
\hline J-stat & 0.623 & & 0.880 & & 0.548 & \\
\hline $\operatorname{AR}(2)$ & 0.600 & & 0.440 & & 0.975 & \\
\hline SITC 2 & $\begin{array}{l}1.375 \\
(3.73)\end{array}$ & $\begin{array}{c}-0.099 \\
(-3.95)\end{array}$ & $\begin{array}{c}0.688 \\
(5.30)\end{array}$ & $\underset{(-2.35)}{-0.055}$ & $\begin{array}{l}0.836 \\
(3.90)\end{array}$ & $\begin{array}{c}-0.104 \\
(-2.10)\end{array}$ \\
\hline J-stat & 0.999 & & 0.989 & & 0.998 & \\
\hline $\operatorname{AR}(2)$ & 0.510 & & 0.243 & & 0.956 & \\
\hline SITC 4 & $\begin{array}{l}0.706 \\
(2.36)\end{array}$ & $\begin{array}{l}-0.353 \\
(-1.23)\end{array}$ & $\frac{1.242}{(5.88)}$ & $\begin{array}{c}0.172 \\
(1.96)\end{array}$ & $\begin{array}{l}0.556 \\
(2.67)\end{array}$ & $\begin{array}{l}0.003 \\
(0.01)\end{array}$ \\
\hline J-stat & 0.998 & & 0.944 & & 0.999 & \\
\hline $\operatorname{AR}(2)$ & 0.685 & & 0.579 & & 0.093 & \\
\hline SITC 5 & $\begin{array}{l}1.363 \\
(5.21)\end{array}$ & $\begin{array}{l}0.001 \\
(0.54)\end{array}$ & $\begin{array}{l}0.637 \\
(4.48)\end{array}$ & $\begin{array}{l}0.000 \\
(-0.20)\end{array}$ & $\begin{array}{l}0.719 \\
(5.87)\end{array}$ & $\frac{0.001}{(2.07)}$ \\
\hline J-stat & 0.309 & & 0.238 & & 0.284 & \\
\hline $\operatorname{AR}(2)$ & 0.617 & & 0.248 & & 0.744 & \\
\hline SITC 6 & $\begin{array}{l}1.517 \\
(6.12)\end{array}$ & $\begin{array}{c}-0.126 \\
(-4.54)\end{array}$ & $\begin{array}{c}0.657 \\
(9.75)\end{array}$ & $\begin{array}{c}-0.010 \\
(-3.75)\end{array}$ & $\begin{array}{l}0.529 \\
(7.42)\end{array}$ & $\begin{array}{c}-0.010 \\
(-3.45)\end{array}$ \\
\hline J-stat & 0.806 & & 0.989 & & 0.990 & \\
\hline $\operatorname{AR}(2)$ & 0.784 & & 0.582 & & 0.134 & \\
\hline SITC 7 & $\begin{array}{l}1.417 \\
(6.80)\end{array}$ & $\begin{array}{l}0.013 \\
(0.65)\end{array}$ & $\begin{array}{c}0.905 \\
(9.83)\end{array}$ & $\begin{array}{c}-0.090 \\
(-1.55)\end{array}$ & $\begin{array}{c}0.998 \\
(9.07)\end{array}$ & $\frac{-0.004}{(-0.05)}$ \\
\hline J-stat & 0.681 & & 0.996 & & 0.993 & \\
\hline $\operatorname{AR}(2)$ & 0.335 & & 0.245 & & 0.088 & \\
\hline SITC 8 & $\begin{array}{c}2.124 \\
(7.20)\end{array}$ & $\begin{array}{c}-0.081 \\
(-1.22)\end{array}$ & $\begin{array}{l}1.415 \\
(9.48)\end{array}$ & $\begin{array}{c}-0.053 \\
(-1.43)\end{array}$ & $\begin{array}{l}1.256 \\
(8.62)\end{array}$ & $\begin{array}{c}-0.033 \\
(-1.06)\end{array}$ \\
\hline J-stat & 0.213 & & 0.909 & & 0.783 & \\
\hline $\operatorname{AR}(2)$ & 0.433 & & 0.055 & & 0.996 & \\
\hline
\end{tabular}

Notes: This table reports the estimated ERPT coefficients from Equation (2). Corresponding $t$-statistics are given between parentheses. Estimation based on extra-UE trade (i.e., after having removed intra-EU trade). 
Table 10 - ERPT and growth in intra-EU trade at the good level

\begin{tabular}{|c|c|c|c|c|c|c|}
\hline \multirow[b]{3}{*}{ SITC } & \multicolumn{2}{|c|}{ Belgium } & \multicolumn{2}{|c|}{ France } & \multicolumn{2}{|c|}{ Germany } \\
\hline & $\theta$ & $\theta^{C}$ & $\theta$ & $\theta^{C}$ & $\theta$ & $\theta^{c}$ \\
\hline & $\begin{array}{c}\text { Coeff. } \\
\text { (t-stat) }\end{array}$ & $\begin{array}{c}\text { Coeff. } \\
\text { (t-stat) }\end{array}$ & $\begin{array}{c}\text { Coeff. } \\
\text { (t-stat) }\end{array}$ & $\begin{array}{c}\text { Coeff. } \\
\text { (t-stat) }\end{array}$ & $\begin{array}{c}\text { Coeff. } \\
\text { (t-stat) }\end{array}$ & $\begin{array}{c}\text { Coeff. } \\
\text { (t-stat) }\end{array}$ \\
\hline SITC $0 \& 1$ & $\begin{array}{c}1.057 \\
(7.54)\end{array}$ & $\begin{array}{c}-0.020 \\
(-2.24)\end{array}$ & $\begin{array}{l}0.623 \\
(11.4)\end{array}$ & $\begin{array}{c}-0.422 \\
(-2.85)\end{array}$ & $\begin{array}{c}0.596 \\
(5.46)\end{array}$ & $\begin{array}{c}-0.022 \\
(-1.96)\end{array}$ \\
\hline J-stat & 0.635 & & 0.973 & & 0.236 & \\
\hline $\operatorname{AR}(2)$ & 0.239 & & 0.277 & & 0.051 & \\
\hline SITC 2 & $\begin{array}{l}1.596 \\
(5.62)\end{array}$ & $\begin{array}{c}-0.016 \\
(-3.70)\end{array}$ & $\begin{array}{l}0.661 \\
(7.84)\end{array}$ & $\begin{array}{c}-0.008 \\
(-1.22)\end{array}$ & $\begin{array}{l}0.790 \\
(6.10)\end{array}$ & $\begin{array}{c}-0.009 \\
(-0.31)\end{array}$ \\
\hline J-stat & 0.995 & & 0.685 & & 0.358 & \\
\hline $\mathrm{AR}(2)$ & 0.793 & & 0.768 & & 0.702 & \\
\hline SITC 4 & $\begin{array}{l}1.764 \\
(3.76)\end{array}$ & $\begin{array}{c}-0.113 \\
(-3.68)\end{array}$ & $\frac{0.605}{(5.11)}$ & $\begin{array}{l}0.023 \\
(1.19)\end{array}$ & $\begin{array}{c}0.850 \\
(5.93)\end{array}$ & $\begin{array}{c}0.006 \\
(0.29)\end{array}$ \\
\hline J-stat & 0.989 & & 0.999 & & 1.000 & \\
\hline $\operatorname{AR}(2)$ & 0.264 & & 0.348 & & 0.220 & \\
\hline SITC 5 & $\begin{array}{l}1.372 \\
(4.63)\end{array}$ & $\begin{array}{l}0.028 \\
(1.02)\end{array}$ & $\begin{array}{l}0.640 \\
(3.61)\end{array}$ & $\begin{array}{c}-0.009 \\
(-0.81)\end{array}$ & $\begin{array}{l}0.685 \\
(5.42)\end{array}$ & $\begin{array}{l}0.013 \\
(0.96)\end{array}$ \\
\hline J-stat & 0.291 & & 0.999 & & 0.310 & \\
\hline $\operatorname{AR}(2)$ & 0.837 & & 0.227 & & 0.982 & \\
\hline SITC 6 & $\frac{1.324}{(6.18)}$ & $\underset{(-0.17)}{-0.002}$ & $\begin{array}{l}0.555 \\
(11.40)\end{array}$ & $\underset{(-2.78)}{-0.111}$ & $\begin{array}{l}0.563 \\
(7.11)\end{array}$ & $\begin{array}{c}-0.014 \\
(-2.38)\end{array}$ \\
\hline J-stat & 0.992 & & 0.310 & & 0.851 & \\
\hline $\operatorname{AR}(2)$ & 0.777 & & 0.215 & & 0.058 & \\
\hline SITC 7 & $\begin{array}{l}1.355 \\
(8.99)\end{array}$ & $\begin{array}{c}-0.007 \\
(-2.55)\end{array}$ & $\frac{0.822}{(7.59)}$ & $\begin{array}{c}-0.044 \\
(-13.20)\end{array}$ & $\begin{array}{c}0.875 \\
(6.99)\end{array}$ & $\frac{0.020}{(1.30)}$ \\
\hline J-stat & 0.673 & & 0.837 & & 0.614 & \\
\hline $\operatorname{AR}(2)$ & 0.350 & & 0.209 & & 0.058 & \\
\hline SITC 8 & $\begin{array}{l}1.879 \\
(3.80)\end{array}$ & $\begin{array}{l}0.020 \\
(1.73)\end{array}$ & $\begin{array}{l}1.362 \\
(12.00)\end{array}$ & $\begin{array}{c}-0.049 \\
(-2.28)\end{array}$ & $\frac{1.214}{(6.98)}$ & $\begin{array}{l}0.014 \\
(0.88)\end{array}$ \\
\hline J-stat & 0.999 & & 0.098 & & 0.999 & \\
\hline $\operatorname{AR}(2)$ & 0.068 & & 0.044 & & 0.048 & \\
\hline
\end{tabular}

Notes: This table reports the estimated ERPT coefficients from Equation (2). Corresponding $t$-statistics are given between parentheses. 


\section{Conclusion}

Assessing the degree of exchange rate pass-through (ERPT) into import prices in eurozone countries is worthy of investigation. Indeed, import prices being a key channel through which exchange rate changes influence domestic prices and, in turn, inflation and output, evaluating the degree of ERPT is a key issue within the context of a monetary union. The same variation in the euro exchange rate change may affect eurozone countries differently, depending on their openness to trade degree. We tackle this issue in the present paper by analyzing ERPT into import prices for three core eurozone countries, namely Belgium, France and Germany, which are characterized by various openness degrees. With protectionism on the rise the question becomes even more relevant.

Relying on a battery of indicators, our results show that globalization plays a limited role in explaining ERPT at the aggregated, country level. The main noticeable exception is Germany for which higher trade openness and intra-industry trade push up the degree of ERPT. Germany has experienced an important rise in trade openness over the period under study, leading to greater competition coming from an increasing share of foreign products in the market and, in turn, raising ERPT. At the disaggregated, sectoral level ERPT degrees differ across countries and there is overall sparse evidence that globalization impacts the pass-through. However, increased globalization apprehended through a rise in the degree of trade openness and a reduction in trade tariffs results in higher ERPT in some sectors. Turning to the "Chinese effect", it is very limited but, when significant, it has the expected sign: a rise in the share of China tends to weaken ERPT, illustrating a threat from competition with this country in the concerned sectors. Overall, even though the effects of globalization on ERPT are quite sparse, we show that regional trade decreases the degree of exchange-rate pass-through in a more generalized way.

Most importantly, our paper puts forward the importance, and even the necessity, to control for intra-EU trade when assessing ERPT into import prices in the case of eurozone countries. Specifically, we show that while ERPT is generally found to be incomplete in the literature, this conclusion is strongly called into question when intra-EU trade is accounted for. Indeed, we find evidence that ERPT into import prices dramatically increases when considering only extra-EU trade, at both the country and the good levels. In most cases, ERPT is close to be complete as exchange rate changes tend to be fully reflected in import prices. In this sense, incompleteness generally observed in the literature is in appearance only and not at play for eurozone countries when intra-EU trade is controlled for. 
On the whole, our results show that ERPT into import prices is significant and complete in numerous sectors, meaning that exchange rate changes still exert very important pressure on domestic prices in the considered eurozone economies. In addition, the responses of import prices to euro exchange rate variations differ across countries and sectors, a characteristic which has to be taken into account for the conduct of the single monetary policy.

\section{References}

Anderton, R. (2003): "Extra-euro area manufacturing import prices and exchange rate pass-through," Working Paper Series 0219, European Central Bank.

Bailliu, J., and E. Fujii (2004): "Exchange Rate Pass-Through and the Inflation Environment in Industrialized Countries: An Empirical Investigation," Staff Working Papers 04-21, Bank of Canada.

Ben Cheikh, N., and C. Rault (2016): "Recent estimates of exchange rate pass-through to import prices in the euro area," Review of World Economics (Weltwirtschaftliches Archiv), 152(1), 69-105.

Benigno, P., and E. Faia (2016): "Globalization, Pass-Through, and Inflation Dynamics," International Journal of Central Banking, 12(4), 263-306.

Bernard, A. B., J. B. Jensen, and P. K. Schott (2006): "Survival of the best fit: Exposure to low-wage countries and the (uneven) growth of U.S. manufacturing plants," Journal of International Economics, 68(1), 219-237.

Betts, C., and M. B. Devereux (2000): "Exchange rate dynamics in a model of pricing-tomarket," Journal of International Economics, 50(1), 215-244.

Bouakez, H., and N. Rebei (2008): "Has exchange rate pass-through really declined? Evidence from Canada," Journal of International Economics, 75(2), 249 - 267.

Burstein, A., and G. Gopinath (2013): "International Prices and Exchange Rates," NBER Working Papers 18829, National Bureau of Economic Research, Inc.

Campa, J., and L. Goldberg (2005): "Exchange Rate Pass-Through into Import Prices," The Review of Economics and Statistics, 87(4), 679-690.

Campa, J., and J. M. Gonzàlez-Mínguez (2006): "Differences in exchange rate pass-through in the euro area," European Economic Review, 50(1), 121-145.

Campa, J. M., L. S. Goldberg, and J. M. Gonzàlez-Mínguez (2005): “Exchange-Rate PassThrough to Import Prices in the Euro Area," Working Paper 11632, National Bureau of Economic Research.

Caves, R. E. (1998): "Industrial Organization and New Findings on the Turnover and Mobility of Firms," Journal of Economic Literature, 36(4), 1947-1982. 
Colantone, I., K. Coucke, and L. Sleuwaegen (2015): "Low-cost import competition and firm exit: evidence from the EU," Industrial and Corporate Change, 24(1), 131-161.

Devereux, M. B., C. Engel, and P. E. Storgaard (2004): “Endogenous exchange rate passthrough when nominal prices are set in advance," Journal of International Economics, 63(2), 263-291.

Devereux, M. B., and J. Yetman (2010): "Price adjustment and exchange rate passthrough," Journal of International Money and Finance, 29(1), 181-200.

Dong, W. (2012): "The role of expenditure switching in the global imbalance adjustment," Journal of International Economics, 86(2), 237 - 251.

Dornbusch, R. (1987): "Exchange Rates and Prices," American Economic Review, 77(1), 93-106.

Engel, C. (2002): "The responsiveness of consumer prices to exchange rates and the implications for exchange rate policy: a survey of a few recent new-open-economy models," Working Paper No. 8725, NBER.

Faruqee, H. (2006): "Exchange Rate Pass-Through in the Euro Area," IMF Staff Papers, 53(1), 63-88.

Gagnon, J. E., and J. Ihrig (2004): "Monetary policy and exchange rate pass-through This article is a U.S. Government work and is in the public domain in the U.S.A." International Journal of Finance \& Economics, 9(4), 315-338.

Gaulier, G., A. Lahrèche-Révil, and I. Méjean (2008): "Exchange-rate pass-through at the product level," Canadian Journal of Economics, 41(2), 425-449.

Gust, C., S. Leduc, and R. Vigfusson (2010): "Trade integration, competition, and the decline in exchange-rate pass-through," Journal of Monetary Economics, 57(3), 309 324.

Hahn, E. (2003): "Pass-through of external shocks to euro area inflation," Working Paper Series 0243, European Central Bank.

Ihrig, J. E., M. Marazzi, and A. D. Rothenberg (2006): "Exchange-rate pass-through in the G-7 countries," International Finance Discussion Papers 851, Board of Governors of the Federal Reserve System (U.S.).

Knetter, M. M. (1989): "Price Discrimination by U.S. and German Exporters," American Economic Review, 79(1), 198-210.

Lipsey, R. E. (1976): “Intra-industry trade: The theory and measurement of international trade in differentiated products: Herbert J. Grubel and P.J. Lloyd, (John Wiley, New York, 1975) pp. 205," Journal of International Economics, 6(3), 312-314.

López-Villavicencio, A., and V. Mignon (2016): "Exchange Rate Pass-through in Emerging Countries: Do the Inflation Environment, Monetary Policy Regime and Institutional 
Quality Matter?," Working Papers 2016-07, CEPII research center.

Marazzi, M., and N. Sheets (2007): "Declining exchange rate pass-through to U.S. import prices: The potential role of global factors," Journal of International Money and Finance, 26(6), $924-947$.

Marazzi, M., N. Sheets, R. Vigfusson, J. Faust, J. Gagnon, J. R. Marquez, R. Martin, T. A. Reeve, and J. Rogers (2005): "Exchange rate pass-through to U.S. import prices: some new evidence," International Finance Discussion Papers 833, Board of Governors of the Federal Reserve System (U.S.).

Milani, F. (2012): "Has Globalization Transformed U.S. Macroeconmic Dynamics?," Macroeconomic Dynamics, 16(2), 204-229.

Monacelli, T. (2005): "Monetary Policy in a Low Pass-through Environment," Journal of Money, Credit and Banking, 37(6), 1047-1066.

Schroder, M., and F. P. Hufner (2002): "Exchange rate pass-through to consumer prices: a European perspective," ZEW Discussion Papers 02 20, ZEW, Center for European Economic Research.

Taylor, J. B. (2000): "Low inflation, pass-through, and the pricing power of firms," European Economic Review, 44(7), 1389-1408. 


\section{Appendix}


Table 11 - SITC classification

\begin{tabular}{|c|}
\hline Section (Panel) and Division (Panel members) \\
\hline 0. Food and live animals \\
\hline 00 - Live animals \\
\hline 01 - Meat and meat preparations \\
\hline 02 - Dairy products and birds' eggs \\
\hline 03 - Fish (not marine mammals), crustaceans, etc. \\
\hline 04 - Cereals and cereal preparations \\
\hline 05 - Vegetables and fruit \\
\hline 06 - Sugars, sugar preparations and honey \\
\hline 07 - Coffee, tea, cocoa, spices, and manufactures thereof \\
\hline 08 - Feeding stuff for animals (not including unmilled cereals) \\
\hline 09 - Miscellaneous edible products and preparations \\
\hline 1. Beverages and tobacco \\
\hline 11 - Beverages \\
\hline 12 - Tobacco and tobacco manufactures \\
\hline 2. Crude materials, inedible, except fuels \\
\hline 21 - Hides, skins and furskins, raw \\
\hline 22 - Oil-seeds and oleaginous fruits \\
\hline 23 - Crude rubber (including synthetic and reclaimed) \\
\hline 24 - Cork and wood \\
\hline 25 - Pulp and waste paper \\
\hline 26 - Textile fibres \\
\hline 27 - Crude fertilizers and crude minerals \\
\hline 28 - Metalliferous ores and metal scrap \\
\hline 29 - Crude animal and vegetable materials, n.e.s. \\
\hline 4 - Animal and vegetable oils, fats and waxes \\
\hline 41 - Animal oils and fats \\
\hline 42 - Fixed vegetable fats and oils, crude, refined or fractionated \\
\hline 43 - Animal or vegetable fats and oils, processed, etc \\
\hline 5 - Chemicals and related products, n.e.s. \\
\hline 51 - Organic chemicals \\
\hline 52 - Inorganic chemicals \\
\hline 53 - Dyeing, tanning and colouring materials \\
\hline 54 - Medicinal and pharmaceutical products \\
\hline 55 - Essential oils, etc \\
\hline 56 - Fertilizers \\
\hline 57 - Plastics in primary forms \\
\hline 58 - Plastics in non-primary forms \\
\hline 59 - Chemical materials and products, n.e.s. \\
\hline 6 - Manufactured goods classified chiefly by material \\
\hline 61 - Leather, leather manufactures, n.e.s., and dressed furskins \\
\hline 62 - Rubber manufactures, n.e.s. \\
\hline 63 - Cork and wood manufactures (excluding furniture) \\
\hline 64 - Paper, paperboard and articles of paper pulp, of paper or of paperboard \\
\hline 65 - Textile yarn, fabrics, made-up articles, n.e.s., and related products \\
\hline 66 - Non-metallic mineral manufactures, n.e.s. \\
\hline 67 - Iron and steel \\
\hline 68 - Non-ferrous metals \\
\hline 69 - Manufactures of metals, n.e.s. \\
\hline 7 - Machinery and transport equipment \\
\hline 71 - Power-generating machinery and equipment \\
\hline 72 - Machinery specialized for particular industries \\
\hline 73 - Metalworking machinery \\
\hline 74 - General industrial machinery and equipment \\
\hline 75 - Office machines and automatic data-processing machines \\
\hline 76 - Telecommunications and sound-recording and reproducing apparatus and equipment \\
\hline 77 - Electrical machinery, apparatus and appliances, n.e.s. \\
\hline 78 - Road vehicles (including air-cushion vehicles) \\
\hline 79 - Other transport equipment \\
\hline 8 - Miscellaneous manufactured articles \\
\hline 81 - Prefabricated buildings; sanitary, plumbing, etc \\
\hline 82 - Furniture, and parts thereof, etc \\
\hline 83 - Travel goods, handbags and similar containers \\
\hline 84 - Articles of apparel and clothing accessories \\
\hline 85 - Footwear \\
\hline 87 - Professional, scientific and controlling instruments and apparatus \\
\hline 88 - Photographic apparatus, equipment and supplies and optical goods, etc \\
\hline 89 - Miscellaneous manufactured articles, n.e.s. \\
\hline
\end{tabular}


Table 12 - ERPT coefficients at the country level. Total trade

\begin{tabular}{|c|c|c|c|}
\hline & \multicolumn{2}{|c|}{ 1992Q1-2016Q4 } & \multirow{2}{*}{$\begin{array}{c}\text { After } \mathbf{2 0 0 2 Q 1} \\
\text { Coeff } \\
(t \text {-stat })\end{array}$} \\
\hline & $\begin{array}{c}\text { Coeff. } \\
\text { (t-stat) }\end{array}$ & $\begin{array}{c}\text { Coeff. } \\
\text { (t-stat) }\end{array}$ & \\
\hline \multicolumn{4}{|l|}{ Belgium } \\
\hline$\theta$ & $\frac{0.402}{(2.17)}$ & $\frac{0.427}{(2.29)}$ & $\frac{0.760}{(2.11)}$ \\
\hline dummy Euro & & $\begin{array}{c}0.934 \\
(1.10)\end{array}$ & \\
\hline \multicolumn{4}{|l|}{ France } \\
\hline$\theta$ & $\begin{array}{l}0.196 \\
(0.98)\end{array}$ & $\begin{array}{c}0.187 \\
(0.93)\end{array}$ & $\begin{array}{c}0.076 \\
(0.22)\end{array}$ \\
\hline dummy Euro & & $\begin{array}{c}0.722 \\
(0.67)\end{array}$ & \\
\hline \multicolumn{4}{|l|}{ Germany } \\
\hline$\theta$ & $\begin{array}{c}0.543 \\
(3.77)\end{array}$ & $\begin{array}{l}0.545 \\
(3.78)\end{array}$ & $\frac{0.903}{(3.70)}$ \\
\hline dummy Euro & & $\begin{array}{c}0.516 \\
(0.59)\end{array}$ & \\
\hline
\end{tabular}

Notes: This table reports the estimated ERPT coefficients from Equation (1). Corresponding $t$-statistics are given between parentheses. Estimation based on total trade (i.e., without excluding intra-EU trade). Dummy euro is a variable that takes the value of 1 for 2002Q1 and all subsequent periods, zero otherwise. 